\title{
Effect of visible light sticks for collecting of adult caddisflies (Trichoptera): A preliminary field study
}

\author{
GORO KIMURA ${ }^{1,2,4, *} \&$ RYOICHI B. KURANISHI ${ }^{3,5}$ \\ ${ }^{1}$ Joint Research Fellow, Natural History Museum and Institute Chiba, 955-2 Aoba-cho, Chuo-ku, Chiba 260-8682, Japan \\ ${ }^{2}$ Technical Research Laboratory, Ikari Shodoku Co., Ltd., 1-12-3 Akanehama, Narashino, Chiba, 275-0024 Japan \\ ${ }^{3}$ Natural History Museum and Institute Chiba, 955-2 Aoba-cho, Chuo-ku, Chiba 260-8682, Japan \\ 4 !" aquat.insects@gmail.com; (1) https://orcid.org/0000-0002-9520-9610 \\ 5 ”cji0820@kmd.biglobe.ne.jp; (10 https://orcid.org/0000-0002-6353-0450 \\ ${ }^{*}$ Corresponding author: "aquat.insects@gmail.com
}

\begin{abstract}
Local residents along the Uji River, Kyoto, Japan, may be exposed to seasonal invasions of adult caddisflies. Ultraviolet (UV)-blocking materials are believed to be an effective pest management tool because adult caddisflies are often attracted to light sources that emit large amounts of UV light. To clarify the effect of the visible spectrum, we collected adult caddisflies using blue, green, and yellow light sticks that did not emit UV light. Traps were operated from 18:30 (sunset: 18:22) on September 2, 2016 to 06:00 (sunrise, 05:31) on September 3, 2016. We collected 382 adults representing eight species of caddisflies. Green light sticks attracted the most numerous individuals (189 adults, seven species), followed by blue (134 adults, seven species), then yellow (59 adults, five species). Paduniella tanidai Nishimoto was the dominant species (331 adults). These results suggest that adult caddisflies are attracted not only to the UV spectrum but also the visible spectrum.
\end{abstract}

Keywords: near-UV light, nuisance, Paduniella tanidai, pest management

\section{Introduction}

Trichoptera eyes are highly sensitive to near-ultraviolet (UV) light radiation (Mikkola, 1972) and vision in the UV range is important for orientation in many species. Faunistic and ecological studies in Trichoptera frequently use black light (UV) traps (e.g., Waringer 1989, 1991, 2003; Nozaki \& Gyotoku 1990; Nishimoto \& Nishimoto 1993; Kimura et al. 2006; Kimura \& Hirabayashi 2008), and occasionally mercury vapor lamps (Nozaki 1988; Nishimoto \& Nishimoto 1997) and daylight fluorescent lamps (Kimura et al. 2008, 2011; Hirabayashi et al. 2011).

The mass emergence of adult aquatic insects often causes a severe nuisance, such as disruption of business, poor visibility, traffic problems, and foul odor (Munroe 1951; Peterson 1952; Osgood 1957; Fredeen 1972). Furthermore, Parlato (1929) identified the hairy wing of caddisfly as an inhalant allergen worldwide. Local residents along the Uji River, Kyoto, Japan, are exposed to seasonal invasions of adult caddisflies, especially hydropsychid species (Kobayashi \& Takemon 2014). However, chemical control of Trichoptera is not economically feasible and has undesirable impacts on other riverine organisms. Therefore, the development of physical and biological control strategies is required along the Uji River.

The use of UV-absorbing materials that block near-UV light radiation has been shown to be effective in preventing different types of pests from entering buildings such as houses and factories. However, Kimura et al. (2014) reported that adult Trichoptera were attracted not only to a white fluorescent lamp (emitting near-UV spectrum) but also a white light emitting diode (LED) lamp (not emitting near-UV spectrum).

Light sticks use energy generated from a chemical reaction to emit light. When the plastic stick is bent, it breaks open a glass vial, and two solutions are mixed together. The chemicals immediately react with one another, starting a chemical reaction that emits light. The articular color dye used in the chemical solution gives 
the light with a distinctive color. To clarify the effect of light not emitting near-UV spectrum, we collected Trichoptera adults using three colors of light sticks.

\section{Materials and Methods}

The present study was conducted at three sampling sites (St.1, St.2, and St.3) near the Uji Bridge in the floodplain of the Uji River, Kyoto Prefecture, Japan (Fig. 1). The annual average maximum and minimum water temperature around the Uji Bridge is $28.9 \pm 1.4 \mathrm{C}^{\circ}$ and $5.4 \pm 1.4 \mathrm{C}^{\circ}$, respectively (Kobayashi \& Takemon 2014). In addition, total nitrogen and total phosphorus around the Uji Bridge is $0.5 \mathrm{~g} / \mathrm{L}$ and $0.025 \mathrm{~g} / \mathrm{L}$, respectively (Kobayashi et al., 2017). For each of three traps at each of the three stations, one light stick (Glowing Light Stick, Daiso Industries Co., Ltd.; $15 \mathrm{~cm}$ in length, $2 \mathrm{~cm}$ in thickness) was mounted $10 \mathrm{~cm}$ over the center of a tray $(26 \mathrm{~cm} \times 35 \mathrm{~cm} \times 5 \mathrm{~cm})$ that was half filled with foaming soap (Mousse Aid Sol Pro, Ikari Shodoku Co., Ltd.) (Fig. 2). Three colors (blue, green, and yellow) of light sticks with pan traps were used at each station. Each light pan trap with its respective color of light stick was set at ground level and was situated approximately $0.5 \mathrm{~m}$ from the water edge. The blue, green, and yellow light-stick traps were located about $10 \mathrm{~m}$ apart from each other at each station. The spectrum of the light sticks was measured 1 min after breaking using a spectrophotometer (USB2000, Ocean Optics Inc., Largo, USA) with an attached sensor fiber placed $0 \mathrm{~cm}$ in front of a light stick. None of the chemical light sticks emitted near-UV spectrum (Fig. 3). The blue, green, and yellow light sticks had peaks at 458, 527, and $570 \mathrm{~nm}$, respectively. The pan traps were operated from 18:30 (sunset at 18:22 on September 2, 2016) to 06:00 (sunrise at 5:31 on September 3, 2016). Adult caddisflies were separated from the other insects. The adults were identified according to the taxonomic keys of Tanida et al. (2005), and individual numbers of each species were counted under a binocular dissecting microscope in the laboratory. In order to compare the Trichoptera fauna among the light sticks, we calculated the Shannon-Wiener diversity index $\left(H^{\prime}\right)$.

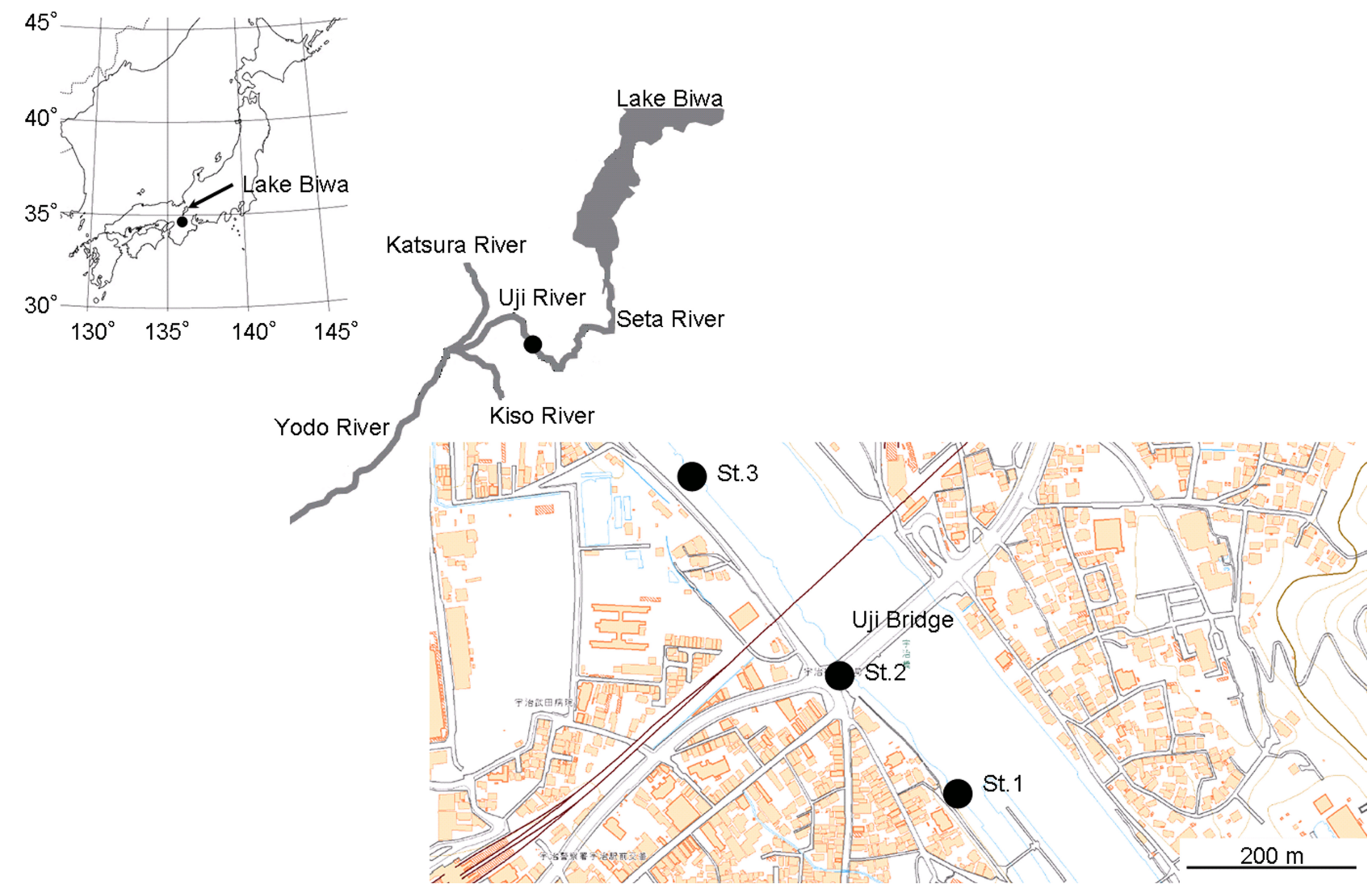

FIGURE 1. Locations of sampling sites. 


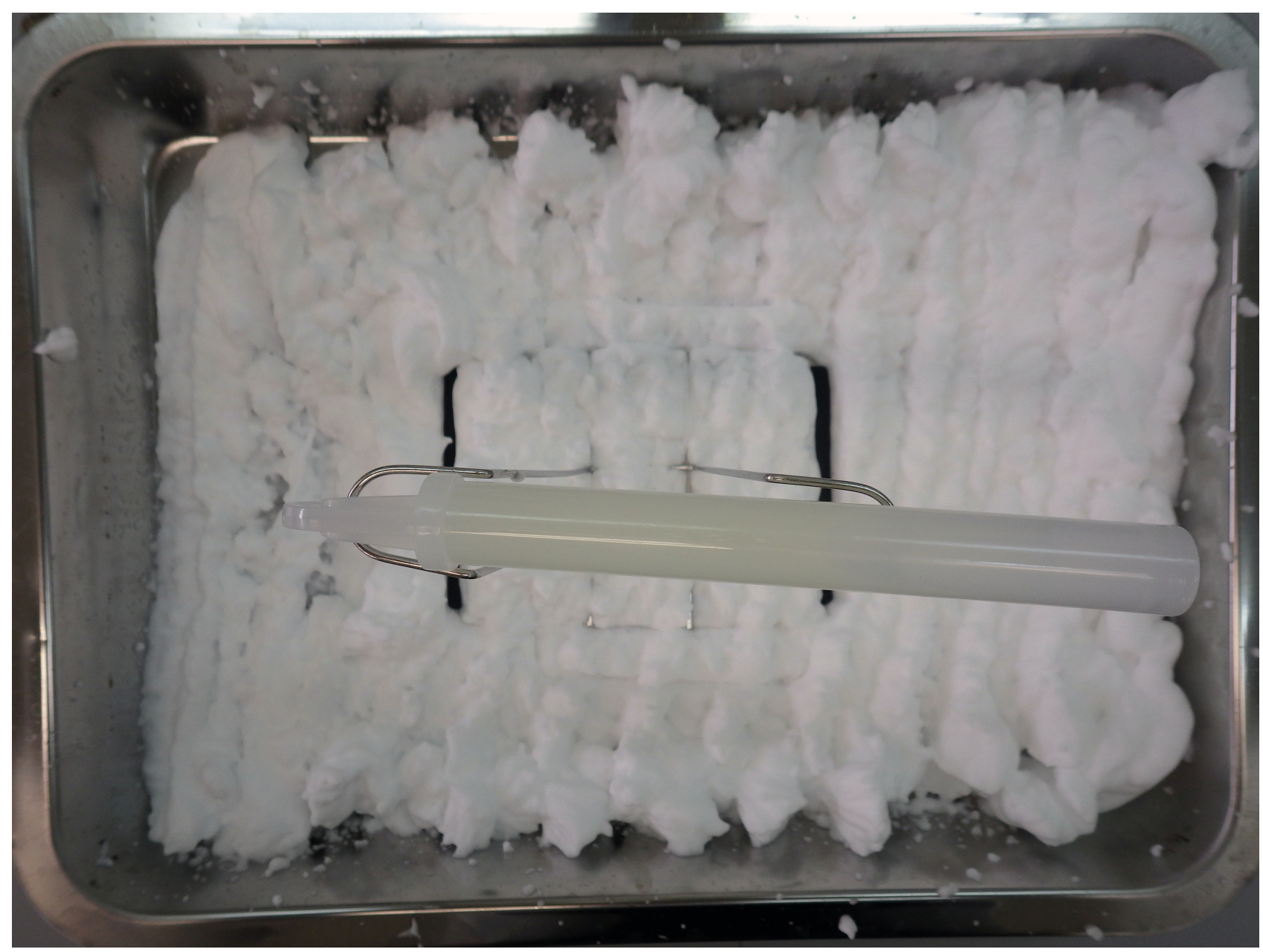

FIGURE 2. Light stick pan trap. The pan was filled with mousse that was for catching and killing adult caddisflies. The light stick was fixed at the center of the pan at a height of about $10 \mathrm{~cm}$.

\section{Results}

A total of 382 (313 males, 69 females) adult Trichoptera were trapped (TABLE 1). We identified eight species in the present study. Seven species were collected using blue and green sticks, and five species were collected with the yellow sticks. Paduniella tanidai Nishimoto 2011 was the most abundant species (331 individuals; 283 males, 48 females; 86.6\% of total Trichoptera), followed by Hydroptila phenianica Botosaneanu 1970 (20 individuals; 10 males, 10 females; $5.2 \%$ of total Trichoptera). The green light sticks collected the most P. tanidai individuals (164 individuals; 141 males, 23 females), followed by the blue sticks (116 individuals; 101 males, 15 females), and the yellow sticks (51 individuals; 41 males, 10 females). Paduniella tanidai, $H$. phenianica, Ecnomus tenellus Rambur 1842, Hydropsyche setensis Iwata 1927, and Trichosetodes japonicus Tsuda 1942 were common to all light sticks. On the other hand, a few adults of Psychomyia sp. and Oecetis antennata (Martynov, 1935) were collected with only green or blue lights, respectively. The Shannon-Wiener diversity index $\left(H^{\prime}\right)$ was highest for blue $(0.88)$, followed by green $(0.86)$ and yellow $(0.81)$ lights.

\section{Discussion}

Our results suggest that Trichoptera respond not only to the UV spectrum but also to the visible spectrum. In particular, the green and blue spectra may be useful for attracting adult Trichoptera. In the sister order of Trichoptera, yellow illumination has been used effectively to control the activity of nocturnal moths and thus 
reduce damage to fruit, vegetables, and flowers (Shimoda \& Honda 2013). Based on results of the present study, the yellow spectrum may be able to control adult Trichoptera activity.

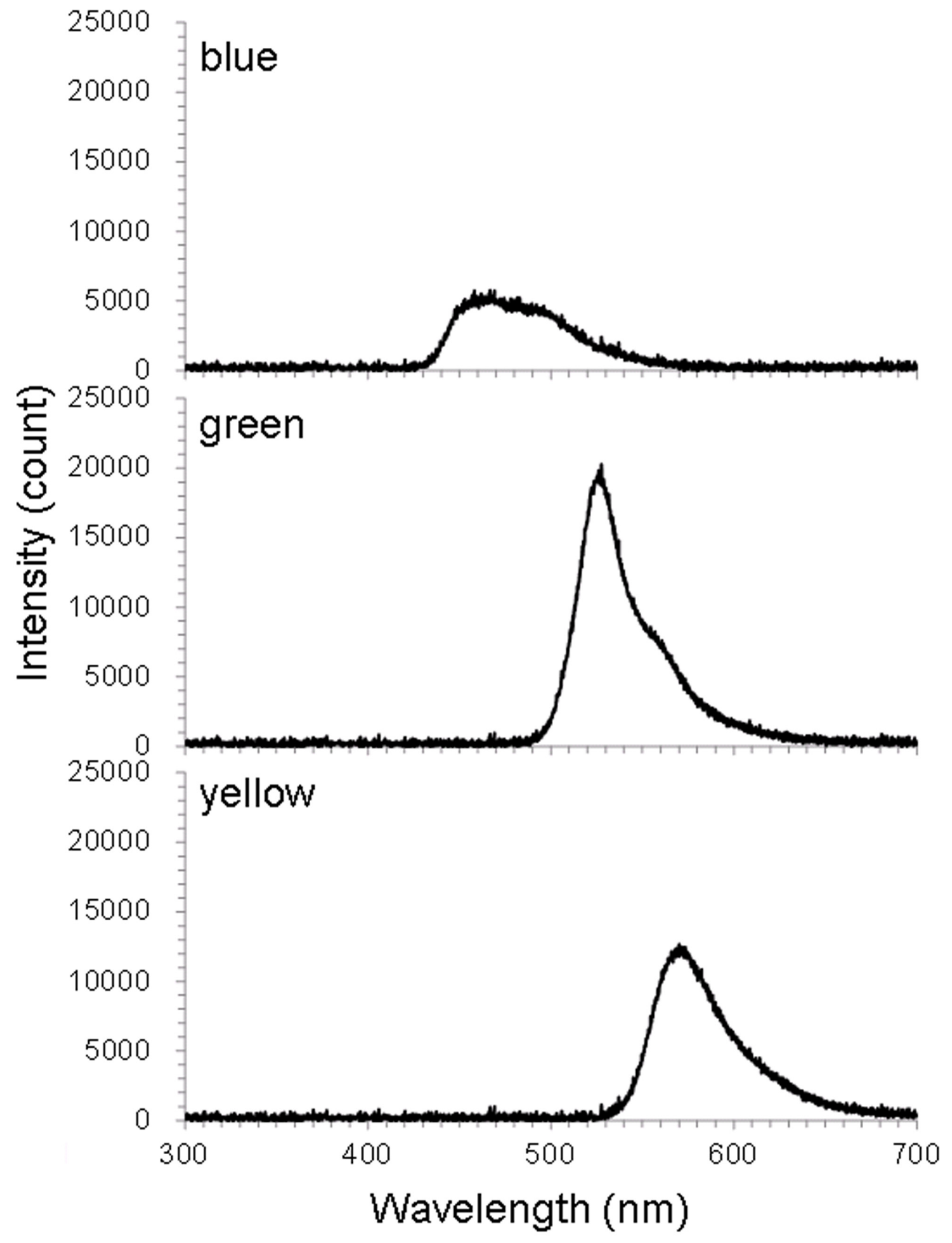

FIGURE 3. Relative spectral distribution of the three light sticks. 


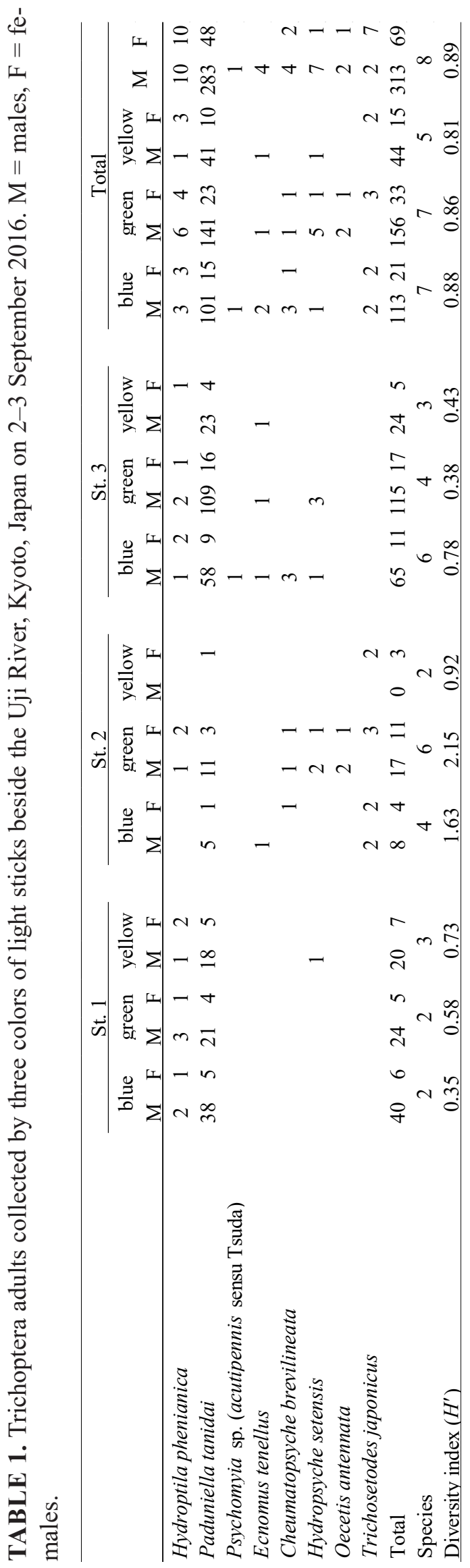


Paduniella tanidai was the dominant species in this study. On the other hand, hydropsychid species was subordinate in this study. The present study suggests that blocking near-UV light radiation may not to be effective in preventing attraction of $P$. tanidai.

Light traps are a powerful sampling method and are useful for faunistic and ecological investigations. In aquatic insects, this method is especially useful for Trichoptera, although other groups such as Diptera (especially Chironomidae) and Ephemeroptera (especially Caenidae) are also often caught in large numbers (Waringer 1989, 2003). In general, light traps require an electric power supply. Price and Baker (2016) demonstrated the feasibility of using small, lightweight, and inexpensive LED-based light traps for studying the biodiversity of aquatic insects in remote locations. On the other hand, light sticks use energy from a chemical reaction to emit light and radiate various wavelengths. These results suggest that light sticks are a useful source of light traps for investigations of Trichoptera.

The sex ratio of the adult Trichoptera, especially of $P$. tanidai, was male-biased during the study period. Previous reports found female-biased sex ratios of caddisflies in light trap samples (Nishimoto \& Nishimoto 1993; Kimura et al. 2008). A female bias may reflect actual larval sex ratios in the river or may be attributed to the light trap selectivity of sexes. The sex ratios of larval populations in the river could not be clarified and compared in the present study.

The most serious pest at Uji River is a hydropsychid species, Macrostemum radiatum (McLachlan 1872), which was not collected in this study. Macrostemum radiatum was attracted to blue sticks at the same time in 2017, and it was suggest that this species were present in 2016 but was not caught by chance.

The present study was conducted during only one summer night; therefore, further follow-up field investigations are necessary to collect more adults using light sticks. Such additional investigations may improve our understanding of trichopteran phototaxis, including that of hydropsychid species.

\section{References}

Botosaneanu, L. (1970) Trichoptères de la République Démocratique-Populaire de la Corée. Annales Zoologici, Warszawa (Poland), 27, 275-359. [in French]

Fredeen, F.-J.-H. (1972) The temporary abatement of nuisance species of Trichoptera with DDD (TDE) larvicide. Canadian Entomologist, 104, 145-163. https://doi.org/10.4039/Ent104145-2

Hirabayashi, K., Kimura, G. \& Inoue, E. (2011) Adult caddisfly (Trichoptera) attached to artificial lights in the middle reaches of the Shinano River from 2005 to 2007. Zoosymposia, 5, 143-146. https://doi.org/10.11646/zoosymposia.5.1.12

Iwata, M. (1927) Trichopterous larvae from Japan. Zoological Magazine, Tokyo (Dobutsugaku Zasshi), 39, 209-272. [in Japanese]

Kimura, G. \& Hirabayashi, K. (2008) Distribution of adult Cheumatopsyche brevilineata (Trichoptera: Hydropsychidae) along the shore of Lake Suwa, Japan. Japanese Journal of Environmental Entomology and Zoology, 19, 133-140.

Kimura, G., Hirabayashi, K. \& Hanazato, T. (2006) Abundance and distribution of adult caddisflies (Trichoptera) caught by light traps in Lake Suwa. In: Nakano, S., Hwang, S.-J., Tanida, K. \& Hirotani, H. (Eds.), Proceedings of the Second Japan-Korea Joint Symposium on Limnology, The Japanese Society of Limnology, Osaka, pp. 1-10.

Kimura, G., Inoue, E. \& Hirabayashi, K. (2008) Seasonal abundance of adult caddisfly (Trichoptera) in the middle reaches of the Shinano River in Central Japan. In: Robinson, W.H. \& Bajomi, D. (Eds.), Proceedings of the 6th International Conference on Urban Pests, OOK-Press Korlátolt felelősségü társaság, Budapest, pp. 259-266.

Kimura, G., Inoue, E. \& Hirabayashi, K. (2011) The effect of a summer flood on the density of caddisfly (Trichoptera) in the middle reaches of the Shinano River, Japan. Zoosymposia, 5, 235-243. https://doi.org/10.11646/zoosymposia.5.1.17

Kimura, G., Harunari, T., Houkita, Y., Kamezawa, K. \& Tanikawa, T. (2014) Insects attracted to light emitting diode (LED) lamps and cold cathode fluorescent lamps. Urban Pest Management, 4, 15-21. [In Japanese with English abstract]

Kobayashi, S. \& Takemon, Y. (2014) Changes in hydrology, water quality, and caddisfly biomass for the past half-century in the Uji River. Annuals of Disaster Prevention Research Institute, Kyoto University, 57B, 561-569. [In Japanese with English abstract]

Kobaysahi, S., Nozaki, T. \& Takemon, Y. (2017) Caddisfly community in the Seta-Uji River, the outlet of Lake Biwa. Japanese Journal of Ecology, 67, 13-29. [In Japanese with English abstract]

Martynov, A.V. (1935) Trichoptera of the Amur Region. Part I. Travaux de l'Institut Zoologique de'l Académie des Sciences de l'URSS, Leningrad, 2, 205-395. [in Russian and English]

McLachlan, R. (1872) Matériaux pour une faune Névroptérologique de l'Asie septentrionale. Annales de la Société Ento- 
mologique de Belgique, 15, 25-77.

Mikkola Kauri (1972) Behavioural and electrophysiological responses of night-flying insects, especially Lepidoptera, to nearultraviolet and visible light. Annales Zoologici Fennici, 9, 225-254.

Munroe, E.G. (1951) Pest Trichoptera at Fort Erie, Ontario. Canadian Entomologist, 83, 69-72. https://doi.org/10.4039/Ent8369-3

Nishimoto, H. (2011) The genus Paduniella (Trichoptera: Psychomyiidae) in Japan. Proceedings of the $13^{\text {th }}$ International Symposium on Trichoptera, Zoosymposia, 5, 381-390. https://doi.org/10.11646/zoosymposia.5.1.30

Nishimoto, F. \& Nishimoto, H. (1993) Fauna of Trichoptera in Aichi Prefecture (I)-Seasonal prevalence of caddisflies collected by the light trap from Sakuragata, Nukata-cho. The Journal of Nagoya Women's University, 39, 83-93. [In Japanese with English abstract]

Nishimoto, F. \& Nishimoto, H. (1997) Fauna of Trichoptera in Aichi Prefecture (II) On Trichoptera in the Kaisho-no-mori Forest in the southeast area of Seto City-. The Journal of Nagoya Women's University, 44, 147-154. [In Japanese with English abstract]

Nozaki, T. (1988) A list of caddisflies collecting with light traps in the Tanzawa mountains, Kanagawa, Japan. Aquatic Organisms of Kanagawa Prefecture, 10, 37-43. [in Japanese]

Nozaki, T. \& Gyotoku, N. (1990) Seasonal change of caddisflies (Trichoptera; Insecta) from daily light trap collection on Chikushino City, northern Kyushu, Japan. Biology of Inland Waters, 5, 10-17. [In Japanese with English abstract]

Osgood, H. (1957) Allergy to caddis fly (Trichoptera). I. Journal of Allergy, 28, 113-123. https://doi.org/10.1016/0021-8707(57)90017-5

Parlato, S. J. (1929) The case of coryza asthma due to sandflies (caddis flies). Journal of Allergy, 1, 35-42. https://doi.org/10.1016/S0021-8707(29)90082-4

Peterson, D.G. (1952) Observations on the biology and control of pest Trichoptera at Fort Erie, Ontario. Canadian Entomologist, 84, 103-107. https://doi.org/10.4039/Ent84103-4

Price, B. \& Baker, E. (2016) NightLife: A cheap, robust, LED based light trap for collecting aquatic insects in remote areas. Biodiversity Data Journal, 4: e7648. https://doi.org/10.3897/BDJ.4.e7648

Rambur, P. (1842) Histoire Naturelle des Insectes Névroptères. Librairie Encyclopédique de Roret, Paris, xviii +534 pp, 12 plates.

Shimoda, M. \& Honda, K. (2013) Insect reactions to light and its applications to pest management. Applied Entomology and Zoology, 48, 413-421. https://doi.org/10.1007/s13355-013-0219-x

Tanida, K., Nozaki, T., Ito, T. \& Hattori, T. (2005) Trichoptera. In: Kawai, T. \& Tanida, K. (Eds.), Aquatic Insects of Japan: Manual with Keys and Illustrations, Tokai University Press, Kanagawa, pp. 397-572. [in Japanese]

Tsuda, M. (1942) Japanische Trichopteren. I. Systematik. Memoirs of the College of Science, Kyoto Imperial University, Series $B, 17,239-339$. [in German]

Waringer, J.A. (1989) The abundance and temporal distribution of caddisfites (Insecta: Trichoptera) caught by light traps on the Austrian Danube from 1986 to 1987. Freshwater Biology, 21, 387-399. https://doi.org/10.1111/j.1365-2427.1989.tb01371.x

Waringer, J.A. (1991) Phenology and the influence of meteorological parameters on the catching success of light-trapping for Trichoptera. Freshwater Biology, 25, 307-319. https://doi.org/10.1111/j.1365-2427.1991.tb00493.x

Waringer, J.A. (2003) Light-trapping of caddisflies at the Thaya (Lower Austria), a river influenced by pulsating hypolimnetic water release. International Review of Hydrobiology, 88, 139-153.

https://doi.org/10.1002/iroh.200390010 